\title{
Pilot Study of Smartphone Infrared Pupillography and Pupillometry [Erratum]
}

\author{
Solyman O, Abushanab MMI, Carey AR, Henderson AD. Clin Ophthalmol. 2022;16:303-310.
}

On page 306 Supplementary Videos 2 and 3 links are missing.

The links are included here: Supplementary Video 2; Supplementary Video 3.

This error was introduced by the Editorial staff during the editing process and was not picked up before publication.

\section{Publish your work in this journal}

Clinical Ophthalmology is an international, peer-reviewed journal covering all subspecialties within ophthalmology. Key topics include: Optometry; Visual science; Pharmacology and drug therapy in eye diseases; Basic Sciences; Primary and Secondary eye care; Patient Safety and Quality of Care Improvements. This journal is indexed on PubMed Central and CAS, and is the official journal of The Society of Clinical Ophthalmology (SCO). The manuscript management system is completely online and includes a very quick and fair peer-review system, which is all easy to use. Visit http://www. dovepress.com/testimonials.php to read real quotes from published authors. 